\title{
Examination of Fatigue, Well-Being and Life Habits in Children with Cancer Diagnosis
}

\author{
Kanser Tanısı Almış Çocuklarda Yorgunluk, lyilik Hali ve Yaşam Alışkanlıklarının \\ İncelenmesi
}

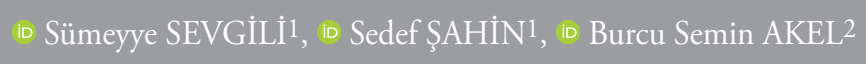

${ }^{1}$ Hacettepe University Faculty of Medicine, Department of Occupational Therapy, Ankara, Turkey

2İstanbul Kültür University, Faculty of Health Sciences, Department of Physiotherapy and Rehabilitation, İstanbul, Turkey

\section{ABSTRACT}

Objective: In this study, it was planned to examine fatigue, wellbeing and life habits in children with cancer.

Methods: This cross-sectional analytical study was conducted between September 2019-January 2020. "24-Hour Child Fatigue Scale", "Child Well-being Assessment" and Child Life Habit Questionnaire (LIFE-H for Children 1.0)" were administered to 20 children with cancer aged 5-15 years. Pearson's correlation coefficient was used to determine the statistical relationship between life habits, fatigue and well-being. Statistical significance level was accepted as $\mathrm{p}<0.05$.

Results: There were significant relationships between fatigue and personal care, shelter and mobility parameters of life habits $(\mathrm{r}=-0.66, \mathrm{r}=0.54, \mathrm{r}=0.45, \mathrm{p}<0.01$, respectively) and there were significant relationships between fatigue and negative emotions $(\mathrm{r}=0.46)$, overall life satisfaction $(\mathrm{r}=-0.52)$, general happiness $(\mathrm{r}=-$ $0.49)$ and positive emotions $\left(r=-0.44^{*}\right)$ parameters of well-being assessment. Life habits scale was found to be related with nutrition, physical fitness and communication parameters of Child Life Habit Questionnaire were found to be most related with the meaning and purpose parameter of the well-being assessment $(\mathrm{p}<0.01)$. There were significant relationships between positive emotions and recreation $(\mathrm{r}=0.45, \mathrm{p}=0.04)$; optimism and communication $(\mathrm{r}=-0.44, \mathrm{p}=0.04)$; personal care $(\mathrm{r}=-0.49, \mathrm{p}=0,02)$, social life $(\mathrm{r}=-0.46, \mathrm{p}=0.04)$ and autonomy; and mobility and negative emotions $(r=-0.45, p=0.04)$.

\section{ÖZ}

Amaç: Bu çalışmada kanser tanısı almış çocuklarda yorgunluk, iyilik hali ve yaşam alışkanlıklarının incelenmesi amaçlandı.

Yöntemler: Kesitsel analitik tipteki bu çalışma, Eylül 2019Ocak 2020 tarihleri arasında gerçekleştirildi. Yaş aralığı 5-15 yıl olan kanser tanısı almış 20 çocuğa "24 Saatlik Çocuk Yorgunluk Ölçeği”, "Çocuklarda İyilik Hali Değerlendirmesi” ve Çocuk Yaşam Alışkanlığı Anketi (LİFE-H for Children 1.0)" uygulandı. Yaşam alışkanlıkları, yorgunluk ve iyilik hali arasında istatistiksel olarak ilişkiyi belirlemek için Pearson korelasyon katsayısı kullanıldı. İstatistiksel anlamlılık düzeyi $\mathrm{p}<0,05$ olarak kabul edildi.

Bulgular: Yorgunluk ile yaşam alışkanlıkları parametrelerinden kişisel bakım, barınma ve mobilite arasında (sırasıyla; $r=-0,66$, $r=0,54, r=0,45 ; p<0,01)$ ve iyilik hali değerlendirmesinin negatif duygular $(r=0,46)$, genel yaşam doyumu $(r=-0,52)$, genel mutluluk $(\mathrm{r}=-0,49)$ ve pozitif duygular $(\mathrm{r}=-0,44)$ arasında anlamlı ilişki saptandı. Çocuk Yaşam Alışkanlığı Anketindeki beslenme, fiziksel uygunluk ve iletişim parametreleri ile en fazla iyilik halinin anlam ve amaç parametresi arasında ilişkili bulundu $(\mathrm{p}<0,01)$. Rekreasyon ile pozitif duygular $(r=0,45, p=0,04)$, iletişim ile iyimserlik $(r=-0,44$, $\mathrm{p}=0,04)$, kişisel bakım $(\mathrm{r}=-0,49, \mathrm{p}=0,02)$ ve toplumsal yaşam $(\mathrm{r}=-$ $0,46, \mathrm{p}=0,04)$ ile otonomi arasında, mobilite ile negatif duygular $(\mathrm{r}=-0,45, \mathrm{p}=0,04)$ arasında anlamlı ilişki görüldü.

Sonuç: $\mathrm{Bu}$ çalışmada tespit edilen ilişkiler dikkate alınarak kanser tanılı çocukların değerlendirmesi ve tedavi yaklaşımları
Address for Correspondence: Sümeyye SEVGiLi, Hacettepe University Faculty of Medicine, Department of Occupational Therapy, Ankara, Turkey

E-mail: smyyesevgili@gmail.com ORCID ID: orcid.org/0000-0002-5341-9281
Received: 08.04.2020

Accepted: 30.09 .2020

Cite this article as: Sevgili S, Şahin S, Akel BS. Examination of Fatigue, Well-Being and Life Habits in Children with Cancer Diagnosis. Bezmialem Science 2021;9(4):439-49. 
Conclusion: Considering the relationships determined in this study, the evaluation of the children with cancer and treatment approaches can be shaped. The fact that fatigue affects all aspects of children's life reveals the importance of dealing with fatigue. It is recommended to focus on the meaning and purpose and regain autonomy for children in order to rearrange the life habits of the children and ensure their well-being.

Keywords: Cancer, child, fatigue, life habits, wellbeing şekillendirilebilir. Yorgunluğun, çocukların yaşamının bütün boyutlarını etkilemesi yorgunlukla başa çıkmanın önemini ortaya koymaktadır. Çocukların yaşam alışkanlıklarının yeniden düzenlenebilmesi ve iyilik halinin sağlanması için anlam ve amaç üzerine odaklanmak ve çocuklara otonomi kazandırmak önerilmektedir.

Anahtar Sözcükler: Kanser, çocuk, yorgunluk, yaşam alışkanlıkları, iyilik hali

\section{Introduction}

Diagnosis of cancer in childhood is rarer than in adults. Between 2001 and 2010, diagnosis of childhood cancer was $13 \%$ more common than in the 1980 s, and its incidence in the $0-14$ age group was 140 per million $(1,2)$. Today, $70 \%$ of children diagnosed as having cancer recover, but 30\% die due to recurrence of the disease and lack of response to treatment (35). Although it was important how the treatment process would progress in diseases such as cancer in the past, psychosocial issues have started to attract more attention with the prolongation of life expectancy $(6,7)$. Therefore, the effects of cancer treatment on physical and psychosocial well-being and quality of life have become increasingly important (8).

Cancer and chemotherapy generally leads to symptoms such as joint and muscle pain, fatigue, edema, growth retardation, fatigue, anxiety, depression, sleep disorder, increased cytokine production, cachexia, decreased physical function, anemia, anger, frustration, isolation from daily life, and introversion in children (9). Fatigue is a frequent finding in $70-100 \%$ of children and young patients with cancer (9-11). It can occur at the time of diagnosis and becomes increasingly common as the disease progresses $(12,13)$. Cancer-related fatigue results from the complex effect of physical, mental, emotional, environmental and pathological factors $(12,14)$. Fatigue, which is a subjective and multidimensional experience, negatively affects the lives of patients with cancer. Therefore, it is very important to evaluate fatigue in cancer from the patient's perspective $(15,16)$.

Studies on well-being have increased in recent years $(17,18)$. Thomas used an expression for well-being as "it is abstract, difficult to define and even harder to measure" (19). Well-being is a subjective expression and includes much more than the concept of happiness (20). It is reported that well-being consists of three interrelated components: Satisfaction with life, positive and negative emotions (21). Studies on the well-being of children with cancer have increased in recent years $(22,23)$.

Life habits are defined as "the daily activities and social roles necessary to ensure the survival and self-development of a person throughout life" (24). In the latest version of the International Classification of Functioning, Disability and Health (ICF), "Disability and Health" is defined as participation of a person in relation to his/her life and nine activities that have an impact on participation are listed as follows: Learning and application of knowledge, general tasks and needs, communication, mobility, personal care, home life, interpersonal interaction and relationships, major living spaces and communal, social and civic life. The World Health Organization emphasizes the necessity of benefiting from this activity list when evaluating life habits (25). Although there are reports in the literature on life habits, they do not cover all parts that a child participates in life or all aspects of these parts (26-29).

The stability of the well-being of individuals depends on a dynamic balance $(30,31)$, and this balance includes parameters such as physical well-being, large amount of physical resources, absence of fatigue, emotional control, social functionality, and activities $(32,33)$. Fatigue can change physical condition, psychological and spiritual self, cognitive functioning, expectations and quality of life (34). Curt found in his study that fatigue affected every aspect of daily life and stated that these were related to the physical, emotional, psychological and social consequences of fatigue (15). Children may not be aware of changes in fatigue, physical endurance, and activities of daily life, but children over the age of 13 may notice a lack of energy (35). It is known that many components change simultaneously in the lives of children with cancer. However, there is no study in the literature examining the relationship between fatigue, wellbeing and life habits in children.

The aim of this study is to evaluate the fatigue, well-being and life habits that are thought to affect the treatment process in children diagnosed as having cancer and to examine the relationship between them.

\section{Method}

\section{Type of Research}

This research was a cross-sectional analytical type study.

\section{Population-Sample of the Research}

In this study, which was carried out between September 2019 and January 2020, all children between the ages of 5-15 who were hospitalized in the pediatric department of Hacettepe University Oncology Hospital, were diagnosed as having cancer, were not in the terminal phase, and in whom treatment was started were included. Twenty children, 11 girls and 9 boys, who completed the questionnaires in time, formed the sample of the study. 


\section{Data Collection Tools}

Research data were collected using the "Child and Parent Information Form, 24-Hour Child Fatigue Scale, Child WellBeing Assessment and Child Life Habit Questionnaire".

Child and Parent Introduction Form: This form was created by researchers to determine the introductory characteristics of children and parents. In the form, five questions were about children's age, gender, education level; and five questions were about parents' age, education level, occupation, income status and family type. According to the information obtained by the parents, the children who got a passing grade in their classes were considered to be successful at a "moderate level" in terms of school success; children with grades above the class average were considered to be successful at "good level".

The 24-Hour Child Fatigue Scale: It was developed in 2001 by Hinds et al. (36) and revised in 2007 to shorten it. The Turkish validity and reliability of the scale was performed by Gerçeker and Yllmaz (37) in 2010. This scale, which is the 24-hour form of the child fatigue scale, includes 10 items questioning whether the child has been tired in the last 24 hours. It includes 5 different options for each item as "not at all, a little, some, quite a bit, and a lot" and each item is scored between 1-5. A minimum of 10 and a maximum of 50 points are obtained from the scale. As the scores obtained from the scale increase, the child's fatigue level increases (37).

The Child Well-being Assessment: It consists of 21 questions included in the New Economics Foundation publication, Guide for Measuring Children's Well-being, and each question is answered by the child $(38,39)$. Translation of the scale was carried out in accordance with the Beaton translation protocol (40). The questions were grouped under four main headings as "well-being dimension, general life satisfaction, general happiness, positive and negative emotions". The well-being dimension consists of sub-parameters such as "positive emotions, negative emotions, life satisfaction, vitality, optimism, resilience, autonomy, meaningful and purposeful activities, relationships". Low scores in optimism, autonomy, meaningful and purposeful activities, and relationships have positive meaning. High scores in the resilience parameter have negative meaning. These parameters are answered as "agree" or "disagree". In general life satisfaction, the child indicates where his/her life is on a ladder with steps between 0-10. In general happiness, the child chooses one of the facial expressions, these are scored between 1-5 and a high score indicates that the child is happy. The positive and negative emotions part includes 5 different options for each question as "never, one day, a few days, most days, and every day" and is scored between 1-5. A high score for positive emotions and a low score for negative emotions indicate a positive state of well-being. The scoring of most parameters is different from each other. The parameters with a total score of 5 are positive emotions 1 , negative emotions 1 and vitality parameters. The parameter with a total score of 3 is life satisfaction parameter. The parameter with a total score of 2 are optimism, resilience, autonomy, meaningful and purposeful activities, and relationships. The total score of the positive emotions parameter is 25 , and the total score of the negative emotions parameter is 20 (38).

Child Life Habit Questionnaire: This questionnaire was developed by Noreau et al. (41) in 2002. It is a form consisting of 12 groups under the main headings of "nutrition, physical fitness, personal care, communication, accommodation, mobility, responsibilities, interpersonal relations, social life, education, work, recreation" and containing a total of 64 questions with a total score of 10. For each life habit, it is required to answer two questions: Level of success and type of assistance. In this form, which is a special scoring method, a high score has a positive value in terms of the child's participation in the activity (41). The translation of the questionnaire was done in accordance with the Beaton principle (40). Considering that the children did not have any working activities, the "work" parameter of the life habit form was not included in the study.

\section{Data Collection Method}

The data were collected by the researcher between September 2019 and January 2020, using the face-to-face interview technique with children in whom treatment was started at Hacettepe University Oncology Hospital and who were hospitalized. Child and Parent introduction forms were filled by the researcher with the help of the parents through face-to-face interview technique.

\section{Ethical Aspect of Research}

The children participating in the study and their parents were informed about the purpose of the study and a signed informed consent form was obtained from the parents. The study was approved by the Hacettepe University Non-interventional Clinical Research Ethics Committee (GO/677).

\section{Evaluation of Data}

The SPSS 17.00 program was used for statistical analysis of the data. Variables determined by measurement were expressed as mean \pm standard deviation. Percentage (\%) was calculated for variables determined by counting. The normal distribution of the variables was examined with the Kolmorov-Smirnov test. "Pearson correlation coefficient" was used to examine the relationship between life habits, fatigue and well-being, all of which had normal distribution Statistical significance level was accepted as $\mathrm{p}<0.05$. The coefficient strength of the correlation and the level of relationship were as follows: $0.00-0.25$ very weak, 0.26-0.49 weak, 0.50-0.69 moderate, 0.70-0.89 high, 0.90-1.0 very high (42).

\section{Results}

The mean age of the children participating in the study was $11.25 \pm 3.04$ years (minimum 5; maximum 15 years), and the mean age of their parents was $40.20 \pm 7.31$ years. It was determined that $55 \%$ of the children were girls, $60 \%$ were attending secondary school, $65 \%$ had good school success, and $80 \%$ knew the diagnosis of the disease. It was determined that $45 \%$ of the parents were primary school graduates, $15 \%$ were 
self-employed, $70 \%$ received minimum wage, and $85 \%$ had nuclear family type (Table 1 ).

The mean score of the participants in the 24-Hour Child Fatigue Scale $(29.40 \pm 9.42)$ was found to be moderate (Table 2).

In the Child Well-being Assessment of the children participating in the study, their general life satisfaction $(7.40 \pm 2.45)$ was found to be above the average, and their general happiness $(3.85 \pm 1.03)$ was at a moderate level. In the title of Positive and Negative Emotions; the scores of negative emotions $1(3.05 \pm 0.60)$ and negative emotions $2(12.40 \pm 2.56)$ parameters were more than moderate level, the scores of positive emotions $1(3.70 \pm 0.57)$ and positive emotions $2(14.40 \pm 3.83)$ parameters were found to be less than moderate level (Table 3 ).
In the Life Habits Form, the score of personal care parameter $(4.85 \pm 2.84)$ was below the average. The scores of mobility parameter (5.14 \pm 3.43$)$, social life parameter (5.66 \pm 4.69$)$, recreation parameter $(5.40 \pm 2.19)$, and accommodation parameter $(5.35 \pm 2.74)$, which included the individual's domestic activities, were found to be at moderate level (Table 4).

There was no significant relationship between the descriptive characteristics of the children and their fatigue and well-being ( $p>0.05$ ). However, a moderate correlation was found between the age and education level of the children and the nutrition, communication and responsibility steps of their life habits and between the school success of the children and the personal care and communication parameters of their life habits $(\mathrm{p}<0.05)$ (Table 5).

Table 1. Introductory characteristics of children and their parents $(n=20)$

\begin{tabular}{|c|c|c|c|}
\hline & & $\mathrm{n}$ & $\%$ \\
\hline \multirow[t]{2}{*}{ Mean age of the children } & \multicolumn{3}{|c|}{$11.25 \pm 3.04$ (minimum 5; maximum 15) } \\
\hline & Girl & 11 & 55.0 \\
\hline \multirow{2}{*}{ Gender of children } & Boy & 9 & 45.0 \\
\hline & Primary school & 7 & 35.0 \\
\hline \multirow[t]{3}{*}{ Education level of children } & Middle school & 12 & 60.0 \\
\hline & Not started school & 1 & 5.0 \\
\hline & Not started school & 1 & 5.0 \\
\hline \multirow[t]{2}{*}{ School success of children } & Moderate & 6 & 30.0 \\
\hline & Good & 13 & 65.0 \\
\hline \multirow{3}{*}{ Awareness of children about their disease } & Know & 16 & 80.0 \\
\hline & Do not know & 4 & 20.0 \\
\hline & Illiterate & 1 & 5.0 \\
\hline \multirow{4}{*}{ Education level of parents } & Primary school & 9 & 45.0 \\
\hline & Middle school & 1 & 5.0 \\
\hline & High school or its equivalent & 5 & 25.0 \\
\hline & Faculty & 4 & 20.0 \\
\hline \multirow{5}{*}{ Occupation of parents } & Housewife & 9 & 45.0 \\
\hline & Officer & 5 & 25.0 \\
\hline & Self-employment & 3 & 15.0 \\
\hline & Retired & 2 & 10.0 \\
\hline & Other & 1 & 5.0 \\
\hline \multirow{3}{*}{ Income of parents } & Below minimum wage & 3 & 15.0 \\
\hline & Minimum wage & 14 & 70.0 \\
\hline & Above minimum wage & 3 & 15.0 \\
\hline \multirow{3}{*}{ Family type } & Nuclear & 17 & 85.0 \\
\hline & Large & 2 & 10.0 \\
\hline & Broken & 1 & 5.0 \\
\hline
\end{tabular}

Table 2. Mean scores of the 24-hour child fatigue scale

\begin{tabular}{l|l} 
& Minimum \\
\hline Fatigue & 11.00
\end{tabular}

Maximum

46.00

\section{Mean \\ 29.40}

Standard deviation

9.42 
Table 3. Mean scores of the child well-being assessment

\begin{tabular}{|c|c|c|c|c|c|}
\hline & & Minimum & Maximum & Mean & Standard deviation \\
\hline \multirow{13}{*}{ Well-being status } & Positive emotions 1 & 3.00 & 5.00 & 3.70 & 0.57 \\
\hline & Negative emotions 1 & 2.00 & 4.00 & 3.05 & 0.60 \\
\hline & Life satisfaction & 1.00 & 3.00 & 2.30 & 0.73 \\
\hline & Vigor & 1.00 & 5.00 & 3.30 & 0.97 \\
\hline & Optimism & 1.00 & 2.00 & 1.20 & 0.41 \\
\hline & Robustness & 1.00 & 1.00 & 1.00 & 0.00 \\
\hline & Autonomy & 1.00 & 2.00 & 1.25 & 0.44 \\
\hline & Meaning and purpose & 1.00 & 2.00 & 1.05 & 0.22 \\
\hline & Relationships & 1.00 & 1.00 & 1.00 & 0.00 \\
\hline & General life satisfaction & 3.00 & 10.00 & 7.40 & 2.45 \\
\hline & General happiness & 2.00 & 5.00 & 3.85 & 1.03 \\
\hline & Positive emotions 2 & 8.00 & 25.00 & 14.40 & 3.83 \\
\hline & Negative emotions 2 & 7.00 & 17.00 & 12.40 & 2.56 \\
\hline
\end{tabular}

Table 4. Mean scores of the child life habit questionnaire

\begin{tabular}{|c|c|c|c|c|c|}
\hline & & Minimum & Maximum & Mean & Standard deviation \\
\hline Life habits & $\begin{array}{l}\text { Nutrition } \\
\text { Physical Fitness } \\
\text { Personal care } \\
\text { Communication } \\
\text { Shelter } \\
\text { Mobility } \\
\text { Responsibility } \\
\text { Interpersonal communication } \\
\text { Communal living } \\
\text { Education } \\
\text { Recreation }\end{array}$ & $\begin{array}{l}0.00 \\
1.48 \\
1.11 \\
0.28 \\
1.11 \\
0.00 \\
2.59 \\
1.78 \\
0.00 \\
0.00 \\
2.22\end{array}$ & $\begin{array}{l}10.00 \\
10.00 \\
10.00 \\
10.00 \\
10.00 \\
10.00 \\
10.00 \\
10.00 \\
10.00 \\
10.00 \\
9.11\end{array}$ & $\begin{array}{l}6.30 \\
6.81 \\
4.85 \\
8.62 \\
5.35 \\
5.14 \\
7.37 \\
8.70 \\
5.66 \\
6.00 \\
5.40\end{array}$ & $\begin{array}{l}2.76 \\
2.19 \\
2.84 \\
2.48 \\
2.74 \\
3.43 \\
2.56 \\
2.21 \\
4.69 \\
4.46 \\
2.19\end{array}$ \\
\hline
\end{tabular}

There was a moderate negative correlation between fatigue and life habits parameters such as personal care, accommodation and mobility $(\mathrm{p}<0.05)$. When the well-being of the children was examined, a weak positive correlation was found between positive emotions 1 and recreation parameter, and between optimism and communication parameter $(\mathrm{p}<0.05)$. Again, a weak negative correlation was found between the autonomy parameter of children and personal care and social life $(\mathrm{p}<0.05)$. In addition, there was a weak negative correlation between the meaning and purpose parameter of children and nutrition and physical fitness, and a high level of negative correlation between the meaning and purpose parameter and communication $(\mathrm{p}<0.05)$, while a weak negative correlation was found between the negative emotions 2 parameter and mobility $(\mathrm{p}<0.05)$. In addition, a weak positive correlation was found between fatigue and negative emotions 1 parameter, a moderate negative correlation was found between fatigue and general life satisfaction parameter, and a weak negative correlation was found between fatigue and general happiness and positive emotions 2 parameters $(\mathrm{p}<0.05)$. These data showed that children's strongest aspects were in communication, life satisfaction, vitality and optimism parameters (Table 6).

When the relationship between the introductory information of the parents and their living habits was examined, no relationship was found other than the age of the parents. There was a weak relationship between parental age and children's responsibility for their life habits $(r=0.46, p=0.04)$, and a moderate relationship between parent age and social life $(\mathrm{r}=0.56, \mathrm{p}=0.01)(\mathrm{p}<0.05)$. A weak correlation was found between family income and wellbeing and positive emotions $1(\mathrm{r}=-0.49, \mathrm{p}=0.02)$ and negative emotions $1 \quad(r=046, p=0.03)$. There was a weak correlation between the number of children of parents and positive emotions $1(\mathrm{r}=0.44, \mathrm{p}=0.04)$, while the number of children of parents and negative emotions $1-2(\mathrm{r}=-0.50, \mathrm{p}=0.02 ; \mathrm{r}=-0.48, \mathrm{p}=0.03$, respectively) parameters were moderately correlated $(\mathrm{p}<0.05)$. 
Table 4. Mean scores of the child life habit questionnaire

Life habits

\begin{tabular}{|c|c|c|c|c|}
\hline & Minimum & Maximum & Mean & Standard deviation \\
\hline Nutrition & 0.00 & 10.00 & 6.30 & 2.76 \\
\hline Physical Fitness & 1.48 & 10.00 & 6.81 & 2.19 \\
\hline Personal care & 1.11 & 10.00 & 4.85 & 2.84 \\
\hline Communication & 0.28 & 10.00 & 8.62 & 2.48 \\
\hline Shelter & 1.11 & 10.00 & 5.35 & 2.74 \\
\hline Mobility & 0.00 & 10.00 & 5.14 & 3.43 \\
\hline Responsibility & 2.59 & 10.00 & 7.37 & 2.56 \\
\hline $\begin{array}{l}\text { Interpersonal } \\
\text { communication }\end{array}$ & 1.78 & 10.00 & 8.70 & 2.21 \\
\hline Communal living & 0.00 & 10.00 & 5.66 & 4.69 \\
\hline Education & 0.00 & 10.00 & 6.00 & 4.46 \\
\hline Recreation & 2.22 & 9.11 & 5.40 & 2.19 \\
\hline
\end{tabular}

Table 5. The relationship between children's life habits and introductory characteristics

\begin{tabular}{|c|c|c|c|c|c|}
\hline & & & Age & Education level & School success \\
\hline \multirow{22}{*}{ Life habits } & \multirow{2}{*}{ Nutrition } & $r$ & $0.53^{*}$ & $0.51 *$ & 0.34 \\
\hline & & $\mathbf{p}$ & 0.01 & 0.02 & 0.14 \\
\hline & \multirow{2}{*}{ Physical fitness } & $r$ & 0.33 & 0.44 & 0.13 \\
\hline & & $p$ & 0.14 & 0.05 & 0.55 \\
\hline & \multirow{2}{*}{ Personal care } & $r$ & 0.16 & 0.12 & $0.48 *$ \\
\hline & & $p$ & 0.47 & 0.61 & 0.03 \\
\hline & \multirow{2}{*}{ Communication } & $r$ & $0.51 *$ & $0.49 *$ & $0.50 *$ \\
\hline & & $\mathbf{p}$ & 0.02 & 0.02 & 0.02 \\
\hline & \multirow{2}{*}{ Shelter } & $r$ & 0.19 & 0.28 & 0.29 \\
\hline & & $p$ & 0.40 & 0.23 & 0.21 \\
\hline & \multirow{2}{*}{ Mobility } & $r$ & 0.35 & 0.34 & 0.25 \\
\hline & & p & 0.12 & 0.13 & 0.28 \\
\hline & \multirow{2}{*}{ Responsibility } & $r$ & $0.47^{*}$ & $0.55^{*}$ & 0.41 \\
\hline & & $\mathbf{p}$ & 0.03 & 0.01 & 0.07 \\
\hline & \multirow{2}{*}{ Interpersonal communication } & $r$ & 0.05 & 0.09 & 0.004 \\
\hline & & $p$ & 0.81 & 0.69 & 0.98 \\
\hline & \multirow{2}{*}{ Communal living } & $r$ & 0.38 & 0.32 & 0.28 \\
\hline & & p & 0.09 & 0.15 & 0.22 \\
\hline & \multirow{2}{*}{ Education } & $r$ & 0.38 & 0.35 & 0.39 \\
\hline & & $p$ & 0.09 & 0.12 & 0.08 \\
\hline & \multirow{2}{*}{ Recreation } & $r$ & 0.32 & 0.40 & 0.37 \\
\hline & & $p$ & 0.16 & 0.07 & 0.10 \\
\hline
\end{tabular}

\section{Discussion}

In our study, it was determined that children diagnosed as having cancer had moderate fatigue and fatigue was mostly associated with personal care, mobility and accommodation, while wellbeing was associated with general life satisfaction and general happiness parameter. Personal care, accommodation, mobility, social life, recreation and responsibility parameters were most affected by the life habits of children. It was observed that the most impairment in well-being was in the areas of resilience, autonomy, positive and negative emotions. It was determined that the most affected life habits were personal care activities and no child could fully perform recreational activities. The physical fitness and communication parameters of life habits were found to be highly correlated with the meaning and purpose parameter, which was the well-being parameter and which questioned whether the activities in one's life were worth living. 


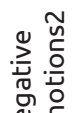

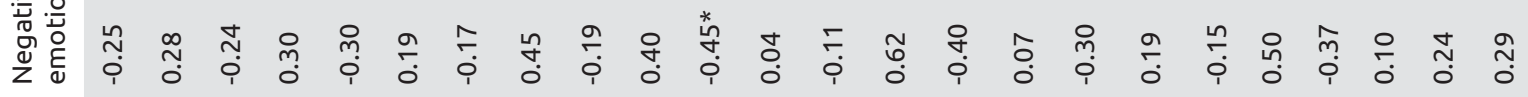

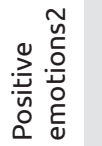

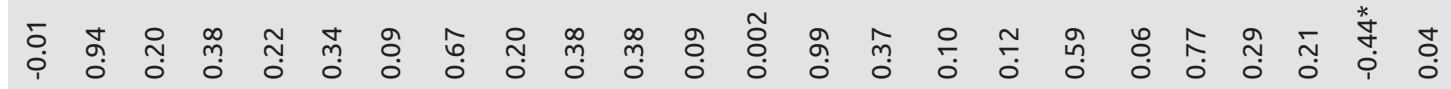

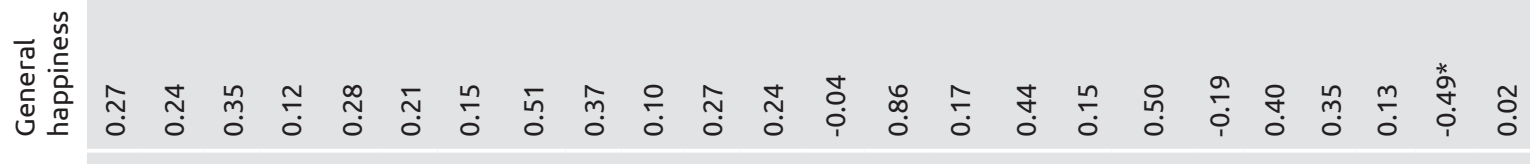
竞: סृ

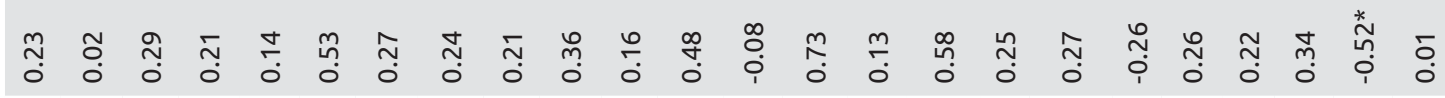

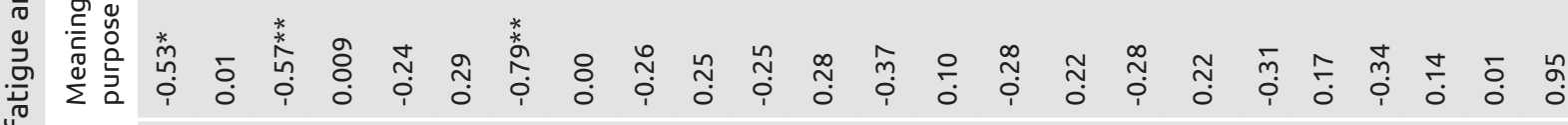
हे

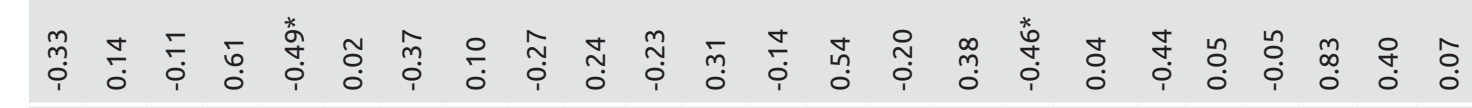

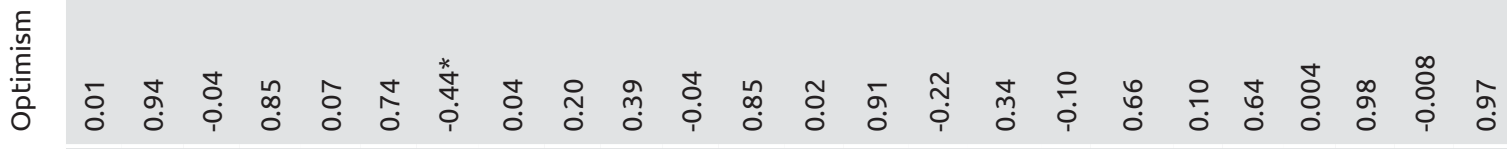

商

岕

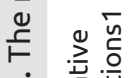

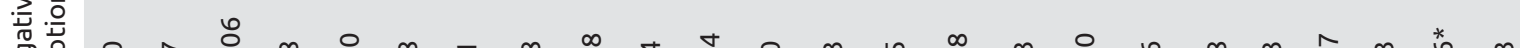

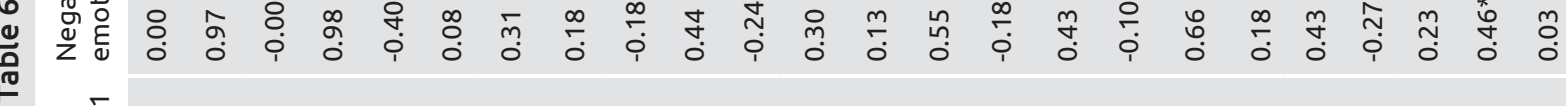
$\stackrel{\bar{n}}{\geq}$

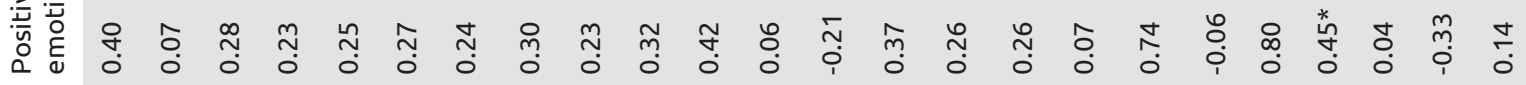

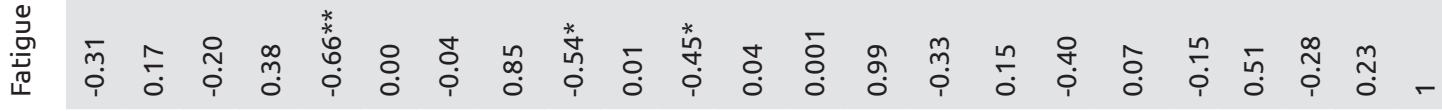

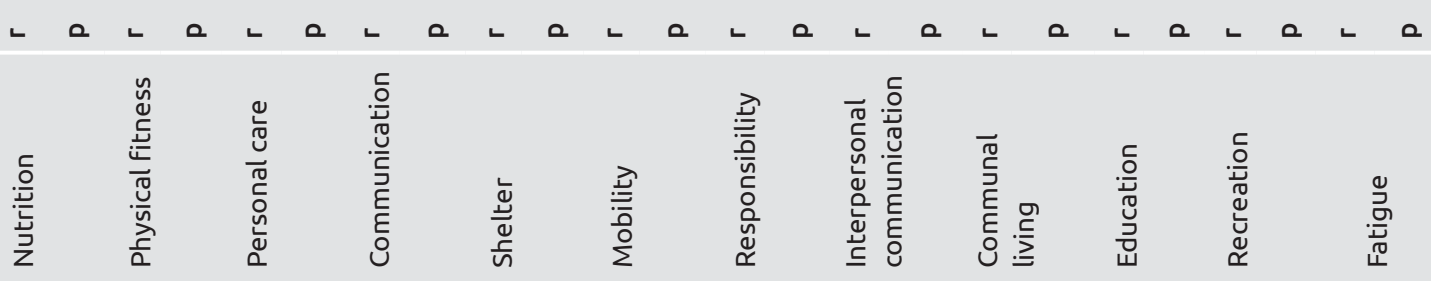


The concerns about fatigue and other physical symptoms that cancer patients usually complain about are ignored by health professionals $(43,44)$. In the literature, there is no study examining the effect of fatigue on life habits in individuals with chronic fatigue, but in the study of Kobayashi et al. (45) in high school and university students, it was found that fatigue did not affect people's life habits except for their physical condition. Fatigue affects the mental well-being of individuals and triggers psychological distress $(46,47)$. It is difficult to understand the fatigue experienced by these children without questioning their daily life and well-being, to understand the effects of fatiguerelated interventions, and to develop coping strategies related to fatigue. Understanding the effects of fatigue in children with chronic health problems is an important step towards improving life habits and well-being. Physical exercises help individuals with chronic diseases to cope with fatigue and improve their well-being (9).

Studies on childhood quality of life are available in the literature $(48,49)$, but studies on well-being are scarce. As a matter of fact, the National Statistics Office opened a discussion on the deficiencies in this regard and emphasized how important wellbeing was for people (50), but only one study on well-being in children was found in our country (51). In our study, it was found that $100 \%$ of the participants agreed with the statement "When something goes wrong in my life, it usually takes a long time to return to normal", which was the question of the robustness dimension of the well-being scale, and their negative emotions were at moderate level. For this reason, the importance of wellbeing in children should not be ignored.

Although studies on activity participation (52-55) are available in the literature, no study is found considering all aspects of children's life habits. In our study, it was observed that fatigue had an effect on life habits in children with cancer. It has been determined that the most affected one is the personal care parameter and it is thought that occupational therapists should mainly work on this issue. The parameters of recreation and social life are affected by the well-being of the person, and the continuity of these life habits, which include the activities that most affect the psychological well-being of an individual, is of great importance for people. Occupational therapists should adapt and maintain these activities for children with chronic diseases.

A relationship was found between parental age and child's life habits, responsibility and social life parameters. It was learned that the protective approach of parents decreased as they got older and they gave more responsibility to their children. In this regard, if the parents are young, education should be given to give up this protective approach and to give their children as much responsibility as necessary.

There are several studies showing that independence in personal care is associated with an increase in the quality of life in children, and it is emphasized that personal care is one of the most important elements of life $(56,57)$. In order to improve personal care, first of all, fatigue should be eliminated. At the same time, the relationship of personal care with well-being should not be ignored. In order to cope with fatigue, occupational therapists should evaluate fatigue with all aspects of a person's life and explain the nature of fatigue to children and their parents. Cooper stated that when leisure time, self-care and productive activities had aerobic component, fatigue could be overcome not only in physical but also in social and cognitive dimensions (9).

While dealing with children, the strengths of children such as communication, life satisfaction, vitality and optimism should not be ignored. The relationship observed between school success and personal care and communication parameters of life habits showed that school success was not only related to success in lessons, but also related to personal care of children. It is thought that the reason for this may be due to the fact that children are not independent in this regard, they cannot continue their routines and due to the difference in their external appearance (eg, hair loss). It has been observed that children need regulations in a way that they will not be isolated from their peers. In order for people to continue their work and productive activities, daily life activities, and leisure time activities in a routine, these activities must be in a certain balance. Considering the information obtained and the balance of activities, it has been determined that correcting the problems seen in children's daily routines, especially personal care activities, can improve school success, which is among the productive activities. Coping with fatigue will help improve self-care and school success.

Impairment in the autonomy section, which questioned whether the well-being of the child let him/her to make free decisions or not, and impairment in the sheltering parameter of life habits, including responsibility and housework, and the fact that sheltering parameter was related to different parameters showed that occupational therapists should focus on this issue. In addition, a relationship was observed between the age and education level of the children and the nutrition, communication and responsibility parameters of their life habits. It is an important finding that should not be overlooked that as the age of the children increases, their responsibilities increase, while they do not take enough responsibility. In many studies, it has been emphasized that as the child gets older, gaining autonomy becomes one of the important goals in the child's life (58-60). Taking this effect into account is very important for the child's psychological well-being. In various studies, it has been emphasized that children with chronic diseases should gradually take responsibility for their diseases as they get older (61-64). Even if their parents are well-intentioned, children begin to see themselves as incompetent because they do not take responsibility as they get older (65). Children must be given responsibility. Educating families in this regard is of great importance for the development of the child's autonomy ability, fulfilling his/her responsibilities and preserving his/her psychological well-being. Giving children home chores at an early age helps to build lasting mastery, responsibility and self-confidence in emotional control in children (66). Parents should give their children responsibility and help develop their autonomy abilities in cooperation with their children or, if necessary, through adaptive methods (67). 
The lack of Turkish validity and reliability of the Child Life Habit Questionnaire and the Child Well-being Assessment emerged as a limitation. It was difficult to apply the questionnaire in children because it was a long questionnaire and we did not have the opportunity to meet beforehand with the children. As a result of our study, it was discovered that if all dimensions of life habits were to be evaluated, pre-recognition was important and evaluations should be done towards noon. The evaluations of those who want to study on children with cancer should be brief. It should be investigated why the resilience dimension of wellbeing was always answered negatively. The relationship between school success and personal care should be examined in detail.

\section{Study Limitations}

The small number of patients, the fact that the patient population included in the study was recruited from a single institution, and the patients' participation in the study during the acute care period were the limitations of our study. The small number of patients affected the generalization of the study. Considering the possibility that the hospital environment may have affected children, it is recommended that different studies be conducted in the home after chemotherapy.

\section{Conclusion}

As a result, our study revealed important parameters that might hinder the life habits, thus daily activities and social roles of Turkish children with cancer. Our study showed that fatigue was an important finding of cancer and its important effects on living habits and well-being should not be ignored.

\section{Ethics}

Ethics Committee Approval: The study was approved by the Hacettepe University Non-Interventional Clinical Research Ethics Committee (GO/677).

Informed Consent: The children participating in the study and their parents were informed about the purpose of the study and a signed informed consent form was obtained from the parents.

Peer-review: Externally peer reviewed.

\section{Authorship Contributions}

Concept: S.S., S.Ş., B.S.A., Design: S.S., B.S.A, Data Collection or Processing: S.S., Analysis or Interpretation: S.S., B.S.A., Literature Search: S.S., Writing: S.S.

Conflict of Interest: No conflict of interest was declared by the authors.

Financial Disclosure: The authors declared that this study received no financial support.

\section{References}

1. Steliarova-Foucher E, Colombet M, Ries LAG, Moreno F, Dolya A, Bray F, et al. International incidence of childhood cancer, 2001-10: a population-based registry study. Lancet Oncol 2017;18:719-31.
2. Agost L. Pediatric renal tumors and their possible relation with endogamous populations in central Argentina. Rev Cubana Pediatr 2019;91:1-18.

3. Cooper TM, Sison EAR, Baker SD, Li L, Ahmed A, Trippett T, et al. A phase 1 study of the CXCR4 antagonist plerixafor in combination with high-dose cytarabine and etoposide in children with relapsed or refractory acute leukemias or myelodysplastic syndrome: A pediatric oncology experimental therapeutics investigators' consortium study (POE 10-03). Pediatr Blood Cancer 2017;64:e26414.

4. Pui CH, Carroll WL, Meshinchi S, Arceci RJ. Biology, risk stratification, and therapy of pediatric acute leukemias: an update. J Clin Oncol 2011;29:551-65.

5. Veerman AJ, Kamps WA, van den Berg H, van den Berg E, Bökkerink JP, Bruin MC, et al. Dexamethasone-based therapy for childhood acute lymphoblastic leukaemia: results of the prospective Dutch Childhood Oncology Group (DCOG) protocol ALL-9 (1997-2004). Lancet Oncol 2009; 10:957-66.

6. James K, Keegan-Wells D, Hinds PS, Kelly KP, Bond D, Hall B, et al. The care of my child with cancer: parents' perceptions of caregiving demands. J Pediatr Oncol Nurs 2002;19:218-28.

7. Van Dongen-Melman JE, Van Zuuren FJ, Verhulst FC. Experiences of parents of childhood cancer survivors: a qualitative analysis. Patient Educ Couns 1998;34:185-200.

8. Gordijn MS, van Litsenburg RR, Gemke RJ, Huisman J, Bierings MB, Hoogerbrugge PM, et al. Sleep, fatigue, depression, and quality of life in survivors of childhood acute lymphoblastic leukemia. Pediatr Blood Cancer 2013;60:479-85.

9. Cooper J. Occupational therapy in oncology and palliative care. West Sussex, UK: John Wiley \& Sons 2013.

10. $\mathrm{Fu} \mathrm{JB}$, Asher A. Exercise therapy and fatigue management. InA. Gulati, V. Puttanniah, B. M. Bruel, W. S. Rosenberg, \& J. C. Hung (Eds.), Essentials of Interventional Cancer Pain Management. New York, NY, USA: Springer. 2019. p. 395-401.

11. Knowles G, Borthwick D, McNamara S, Miller M, Leggot L. Survey of nurses' assessment of cancer-related fatigue. Eur J Cancer Care (Engl) 2000;9:105-13.

12. Berger AM, Walker SN. An explanatory model of fatigue in women receiving adjuvant breast cancer chemotherapy. Nurs Res 2001;50:42-52.

13. Aapro M, Scotte F, Bouillet T, Currow D, Vigano A. A Practical Approach to Fatigue Management in Colorectal Cancer. Clin Colorectal Cancer 2017;16:275-85.

14. Hammick M, Stone P; Cancer Fatigue Forum. Cancer fatigue and its impact on patients: knowledge within the cancer care team. J Interprof Care 2003;17:183-92.

15. Curt GA. The impact of fatigue on patients with cancer: overview of FATIGUE 1 and 2. Oncologist 2000;5:9-12.

16. Porock D, Juenger JA. Just go with the flow: a qualitative study of fatigue in biotherapy. Eur J Cancer Care (Engl) 2004;13:356-61.

17. Zuurmond M, Nyante G, Baltussen M, Seeley J, Abanga J, Shakespeare T, et al. A support programme for caregivers of children 
with disabilities in Ghana: Understanding the impact on the wellbeing of caregivers. Child Care Health Dev 2019;45:45-53.

18. Seligman M. Flourish: A new understanding of happiness, wellbeing-and how to achieve them. London, UK: Nicholas Brealey Pub 2011.

19. Thomas J. Working paper: current measures and the challenges of measuring children's well-being. April. Household, Labour Market and Social Wellbeing, Office for National Statistics, Cardiff Road, Newport, NP10 8XG 2009

20. Marks N, Shah H. A well-being manifesto for a flourishing society. J Public Ment Health 2004;3:9-15.

21. Diener E, Suh E. Measuring quality of life: Economic, social, and subjective indicators. Socl Indi Res 1997;40:189-216.

22. Neville AR, Moothathamby N, Naganathan M, Huynh E, Moola FJ. "A place to call our own": The impact of camp experiences on the psychosocial wellbeing of children and youth affected by cancer - A narrative review. Complement Ther Clin Pract 2019;36:18-28.

23. Storey L, Fern LA, Martins A, Wells M, Bennister L, Gerrand C, et al. A Critical Review of the Impact of Sarcoma on Psychosocial Wellbeing. Sarcoma 2019;2019:9730867.

24. Desrosiers J, Noreau L, Robichaud L, Fougeyrollas P, Rochette A, Viscogliosi C. Validity of the Assessment of Life Habits in older adults. J Rehabil Med 2004;36:177-82.

25. World Health Organization (WHO). International Classification of Functioning, Disability, and Health: Children \& Youth Version:ICFCY. Geneva, CHE: World Health Organization 2007.

26. Bedell GM, Dumas HM. Social participation of children and youth with acquired brain injuries discharged from inpatient rehabilitation: a follow-up study. Brain Inj 2004;18:65-82.

27. Detmar SB, Hosli EJ, Chorus AM, van Beekum T, Vogels T, MouradBaars PE, et al. The development and validation of a handicap questionnaire for children with a chronic illness. Clin Rehabil 2005;19:73-80.

28. King GA, Law M, King S, Hurley P, Hanna S, Kertoy M, et al. Measuring children's participation in recreation and leisure activities: construct validation of the CAPE and PAC. Child Care Health Dev 2007;33:28-39.

29. Law M, Finkelman S, Hurley P, Rosenbaum P, King S, King G, et al. Participation of children with physical disabilities: Relationships with diagnosis, physical function, and demographic variables. Scand J Occup Ther 2004;11:156-62.

30. Headey B, Wearing A. Subjective well-being: A stocks and flows framework. In F. Strack, M. Argyle \& N. Schwarz (Eds.), Subjective Well-being: An Interdisciplinary Perspective. Oxford, UK: Pergamon Press 1991. p. 49-73.

31. Headey B, Wearing AJ. Understanding happiness: A theory of subjective well-being. Melbourne, VIC, AU: Longman Cheshire 1992.

32. Herzlich C. Health and illness: A social psychological analysis (Vol. 5). London, UK: Academic Press, 1973.

33. Abraham C, Sheeran P. Cognitive representations and preventative health behaviour: A review. In K. J. Petrie \& J. A. Weinman (Eds.), Perceptions of Health \& Illnes Third Avenue, NY, USA: Routledge 2013. p. 213-40.
34. Wu HS, McSweeney M. Cancer-related fatigue: "It's so much more than just being tired”. Eur J Oncol Nurs 2007;11:117-25.

35. Hokkanen H, Eriksson E, Ahonen O, Salantera S. Adolescents with cancer: experience of life and how it could be made easier. Cancer Nurs 2004;27:325-35.

36. Hinds PS, Hockenberry M, Rai SN, Zhang L, Razzouk BI, McCarthy $\mathrm{K}$, et al. Nocturnal awakenings, sleep environment interruptions, and fatigue in hospitalized children with cancer. Oncol Nurs Forum 2007;34:393-402.

37. Gerçeker GÖ, Yilmaz HB. Reliability and validity of Turkish versions of the child, parent and staff cancer fatigue scales. Asian Pac J Cancer Prev 2012;13:3135-41.

38. Huppert FA, Baylis N, Keverne B. The Science of Well-being. New York, USA: Oxford University Press 2005.

39. Marks N, Shah H, Westall A. The power and potential of well-being indicators: Measuring young people's well-being in Nottingham. London, UK: New Economics Foundation 2004.

40. Beaton D, Bombardier C, Guillemin F, Ferraz MB. Recommendations for the Cross-Cultural Adaptation of the DASH \& Quick DASH Outcome Measures. Institute for Work Health 2007;1-45.

41. Noreau L, Fougeyrollas P, Vincent C. The LIFE-H: Assessment of the quality of social participation. Technol Disabil 2002;14:113-8.

42. Köse SK. (2008). Korelasyon ve regresyon analizi. Çevrimiçi) http:// tr. scribd. com/doc/2066772/korelasyon-analizi, 9.

43. Davies B, Whitsett SF, Bruce A, McCarthy P. A typology of fatigue in children with cancer. J Pediatr Oncol Nurs 2002;19:12-21.

44. Hockenberry MJ, Hinds PS, Barrera P, Bryant R, Adams-McNeill $\mathrm{J}$, Hooke C, et al. Three instruments to assess fatigue in children with cancer: the child, parent and staff perspectives. J Pain Symptom Manage 2003;25:319-28.

45. Kobayashi H, Demura S, Goshi F, Minami M, Nagasawa Y, Sato $S$, et al. [The relationship among subjective symptoms of fatigue, subjective fatigue feeling, and life habits of high school and college students]. Nihon Eiseigaku Zasshi 1999;54:552-62.

46. Garralda ME, Rangel L. Annotation: Chronic Fatigue Syndrome in children and adolescents. J Child Psychol Psychiatry 2002;43:16976.

47. Van Dam NT, van Vugt MK, Vago DR, Schmalzl L, Saron CD, Olendzki A, et al. Mind the Hype: A Critical Evaluation and Prescriptive Agenda for Research on Mindfulness and Meditation. Perspect Psychol Sci 2018;13:36-61.

48. Engelen V, Koopman HM, Detmar SB, Raat H, van de Wetering MD, Brons P, et al. Health-related quality of life after completion of successful treatment for childhood cancer. Pediatr Blood Cancer 2011;56:646-53.

49. Parsons SK, Fairclough DL, Wang J, Hinds PS. Comparing longitudinal assessments of quality of life by patient and parent in newly diagnosed children with cancer: the value of both raters' perspectives. Qual Life Res 2012;21:915-23.

50. Dodge R, Daly AP, Huyton J, Sanders LD. The challenge of defining wellbeing. International Journal of Wellbeing 2012;2:222-35.

51. Yolcuoğlu İG. Sosyal çalışma ve çocuğun iyilik hali. Toplum ve Sosyal Hizmet 2009;20:85-94. 
52. Allender S, Cowburn G, Foster C. Understanding participation in sport and physical activity among children and adults: a review of qualitative studies. Health Educ Res 2006;21:826-35.

53. Berg C, Neufeld P, Harvey J, Downes A, Hayashi RJ. Late effects of childhood cancer, participation, and quality of life of adolescents. OTJR 2009;29:116-24.

54. Horn TS, Horn JL. Family influences on children's sport and physical activity participation, behavior, and psychosocial responses. In G. Tenenbaum \& R. C. Eklund (Eds.), Handbook of Sport Psychology. Hoboken, NJ, USA: John Wiley \& Sons Inc 2007. p. 685-711.

55. Salmon J, Booth ML, Phongsavan P, Murphy N, Timperio A. Promoting physical activity participation among children and adolescents. Epidemiol Rev 2007;29:144-59.

56. Weissberg-Benchell J, Goodman SS, Antisdel Lomaglio J, Zebracki K. The use of Continuous Subcutaneous Insulin Infusion (CSII): parental and professional perceptions of self-care mastery and autonomy in children and adolescents. J Pediatr Psychol 2007;32:1196-202.

57. Beacham BL, Deatrick JA. Health care autonomy in children with chronic conditions: implications for self-care and family management. Nurs Clin North Am 2013;48:305-17.

58. Allen JP, Hauser ST, Bell KL, O'Connor TG. Longitudinal assessment of autonomy and relatedness in adolescent-family interactions as predictors of adolescent ego development and self-esteem. Child Dev 1994;65:179-94.

59. Collins WA, Gleason T, Sesma A. Jr. Internalization, autonomy, and relationships: Development during adolescence. In J. E. Grusec \& L. Kuczynski (Eds.), Parenting and Children's Internalization of Values: A Handbook of Contemporary Theory. Hoboken, NJ, US: John Wiley \& Sons Inc 1997. p. 78-99
60. Smetana JG. The development of autonomy during adolescence: A social-cognitive domain theory view. In B. Soenens, M. Vansteenkiste, \& S. Van Petegem (Eds.), Autonomy in Adolescent Development: Towards Conceptual Clarity. Hove, UK: Psychology Press 2017. p. 69-89.

61. Andersen RM. Revisiting the behavioral model and access to medical care: does it matter? J Health Soc Behav 1995;36:1-10.

62. Drotar D, Ievers C. Age differences in parent and child responsibilities for management of cystic fibrosis and insulin-dependent diabetes mellitus. J Dev Behav Pediatr 1994;15:265-72.

63. McQuaid EL, Kopel SJ, Klein RB, Fritz GK. Medication adherence in pediatric asthma: reasoning, responsibility, and behavior. J Pediatr Psychol 2003;28:323-33.

64. Annunziato RA, Bucuvalas JC, Yin W, Arnand R, Alonso EM, Mazariegos GV, et al. Self-Management Measurement and Prediction of Clinical Outcomes in Pediatric Transplant. J Pediatr 2018;193:12833.

65. Pomerantz EM, Eaton MM. Developmental differences in children's conceptions of parental control:"They love me, but they make me feel incompetent”. Merrill-Palmer Quarterly 2000;46:140-67.

66. Doinita NE, Maria ND. Attachment and parenting styles. Procedia Soc Behav Sci 2015;203:199-204.

67. Wiebe DJ, Berg CA, Korbel C, Palmer DL, Beveridge RM, Upchurch $\mathrm{R}$, et al. Children's appraisals of maternal involvement in coping with diabetes: enhancing our understanding of adherence, metabolic control, and quality of life across adolescence. J Pediatr Psychol 2005;30:167-78. 